\title{
Pomolic acid induces apoptosis and inhibits multidrug resistance protein MRP1 and migration in glioblastoma cells
}

\author{
LÍVIA PAES TAVARES PACHECO GUIMARÃES, GLEICE DA GRAÇA ROCHA, RAFAELA MUNIZ DE QUEIROZ, \\ CAROLLINA DE ARAUJO MARTINS, CHRISTINA MAEDA TAKIYA and CERLI ROCHA GATTASS
}

\author{
Laboratory of Immunopathology, Institute of Biophysic Carlos Chagas Filho, CCS, \\ Federal University of Rio de Janeiro, 21949-900 Rio de Janeiro, RJ, Brazil
}

Received February 11, 2017; Accepted June 21, 2017

DOI: $10.3892 /$ or.2017.5895

\begin{abstract}
Glioblastoma (GBM), the most aggressive of primary brain tumors, determine short survival and poor quality of life. Therapies used for its treatment are not effective and chemotherapy failure is partially due to multidrug resistance (MDR) mechanisms present in the tumor cells. New therapeutic strategies are needed in order to improve survival in GBM. The present study investigated the activity of the pentacyclic triterpene pomolic acid (PA) in GBM. Pomolic acid decreased the viability and induced apoptosis of GBM cells as demonstrated by DNA fragmentation. It also induced uncoupling of mitochondria membrane potential and activation of caspase-3 and -9. Pomolic acid-induced apoptosis is dependent on reactive oxygen species (ROS) production as it is inhibited by anti-oxidant treatment. Pomolic acid also downmodulated the activity of the multidrug resistance associated protein 1 (MRP1) and inhibited migration of GBM cells. These results show that PA acts on several pathways of GBM drug resistance and therefore may be of potential interest for the treatment of this tumor.
\end{abstract}

\section{Introduction}

Glioblastoma (GBM) is the most common and aggressive glioma, representing $50 \%$ of all gliomas and more than $40 \%$ of all central nervous system (CNS) tumors. The standard GBM treatment, which consists of surgical resection, radiation and/or chemotherapy, is rarely curative. The location of GBM in the central nervous system and its characteristics of a diffuse pattern of growth (diffuse glioma) in the majority

Correspondence to: Dr Cerli Rocha Gattass, Laboratory of Immunopathology, Institute of Biophysic Carlos Chagas Filho, CCS, Federal University of Rio de Janeiro, 21949-900 Rio de Janeiro, RJ, Brazil

E-mail: cerli@biof.ufrj.br

Key words: glioblastoma, pomolic acid, triterpenes, multidrug resistance, cell death, apoptosis, multidrug resistance associated protein 1 of adult patients prevent complete resection of the tumor, requiring additional therapy. Regardless of the initial response to radiation and chemotherapy, the tumor generally recurs within a year after these treatments (1). Tumor cell resistance to chemo-radiation contributes to the poor prognosis of the disease. Indeed, use of chemotherapeutic agents alone or in combination with radiotherapy is unable to improve significantly the median survival time of GBM patients (2). Thus, changes in the outcome of GBM patients remain a challenge.

Several chemotherapeutic drugs act by inducing apoptosis of cancer cells. The apoptotic process is characterized by a series of morphological alterations and biochemical reactions leading to DNA fragmentation and breakdown of the cell into apoptotic bodies. Activation of initiator caspases (caspase-8 and -9), triggered either by activation of death receptors on the plasma membrane (extrinsic pathway) or by stress signals/alterations of the mitochondrial membrane potential (intrinsic pathway), induces the activation of effector caspases (caspase-3, -6 and -7), the main executors of apoptosis (3). Additionally, chemotherapeutic drugs may also act by increasing the generation of reactive oxygen species (ROS) in the target cell. Since mitochondria are the main source of intracellular ROS it has been suggested that the elevated levels of ROS produced in response to stress signals/alterations of mitochondrial membrane potential are relevant for druginduced apoptosis (4).

Drug resistance remains the major cause of death of cancer patients. Among the several mechanisms used by cancer cells to escape death, great attention has been focused on the transporter proteins of the ABC cassette family, such as ABCB1 (P-glycoprotein), the ABCC (multidrug resistance-associated protein) family and $\mathrm{ABCG} 2$ (breast cancer resistance protein). These proteins, which actively remove drugs from cells decreasing their intracellular concentration and preventing death (5), are recognized as an important mechanism of chemoresistance in tumor cells, including GBM $(6,7)$. Although all transporter proteins are present in glioblastoma, members of the MRP family seem to be important for GBM drug resistance as their expression is correlated with a poor patient prognosis (8). Additionally, inhibition of MRP1 increases drug cytotoxicity in GBM (9-11).

Another important factor that contributes to death of GBM patients is the tumor invasiveness. Due to their rapid growth 
and infiltrative characteristics, malignant gliomas are largely incurable even with a combination therapy of surgery, irradiation and chemotherapy (12). Thus, in addition to its resistance to regular chemotherapics, the aggressive proliferation, vascularization and diffuse invasiveness of GBM contribute to its poor prognosis (13). As the tumor infiltrating edges prevent the complete removal of the tumor, leading to recurrence, there is a great interest in therapies to inhibit tumor migration.

Bioactive products of natural origin constitute a source for new agents with pharmacological potential. Among these products, the pentacyclic triterpenes are emerging as a group of substances with many interesting biological effects (14). We focused on pomolic acid (PA), a pentacyclic triterpene isolated from a broad spectrum of plants that show several pharmacological activities (15-17). Pomolic acid inhibits breast cancer cell migration (18) and shows cytotoxicity towards different types of neoplastic cells such as leukemia $(19,20)$, human gastric adenocarcinoma and uterine carcinoma and, murine melanoma (21), human breast cancer (22) and human ovarian adenocarcinoma (23). It is also active against leukemia multidrug resistance cell lines overexpressing P-glycoprotein (Pgp) or Bcl-2 $(19,24)$. However, there are no reports on its activity towards glioblastoma (GBM), a very aggressive brain tumor. This study investigated the in vitro antitumoral activity of PA on human GBM cell lines and explored the mechanisms for its effectiveness. Pomolic acid activates apoptosis through the intrinsic pathway, with an important role of ROS production in the process. Moreover, PA down-modulates the activity of the transporter protein MRP1/ABCC1 and inhibits the migration of GBM cells, two important factors of tumor drug resistance and progression. These results together with previous studies show that PA is also able to act on different pathways of apoptosis resistance, support the potential usefulness of this triterpene for the development of novel therapies to treat patients with GBM and MDR tumors.

\section{Materials and methods}

Cells and reagents. Human glioblastoma cell lines A172, U87 and GBM-1, a cell line established from a GBM tumor biopsy (25) were grown in Dulbecco's modified Eagle's medium (DMEM) supplemented with $10 \%$ heat-inactivated fetal calf serum (FCS), $100 \mathrm{U} / \mathrm{ml}$ penicillin and $100 \mathrm{mg} / \mathrm{ml}$ streptomycin in disposable plastic bottles at $37^{\circ} \mathrm{C}$ with $5 \% \mathrm{CO}_{2}$. Cells were sub-cultured using trypsin-EDTA every 3-4 days.

3-(4,5dimethylthiozol-2-yl)-2,5-diphenyl-tetrazolium bromide (MTT), verapamil, penicillin, streptomycin, $\mathrm{N}$-acetyl-L-cysteine (NAC), propidium iodide (PI), sodium fluoride $(\mathrm{NaF})$, phenylmethylsulfonyl fluoride (PMSF), sodium orthovanadate, RIPA buffer, rhodamine 123 (Rho123) and FITC-labeled goat anti-rat IgG antibody were purchased from Sigma-Aldrich (St. Louis, MO, USA). 5-carboxifluorescein diacetate (5-CFDA) and 2',7'-dichlorofluorescein diacetate $\left(\mathrm{H}_{2}\right.$-DCFDA) were obtained from Calbiochem (San Diego, CA, USA). $\mathrm{DiOC}_{6}(3)$ was from Molecular Probes (Eugene, OR, USA). MK-571 and anti-MRP1 (MRPr1) were provided by Enzo Life Sciences, Inc., (Farmingdale, NY, USA). DMEM, FCS and trypsin-EDTA were from Gibco-BRL (Carlsbad, CA, USA). Caspase-3 and -9 assay kits (CaspGLOW) were from BioVision, Inc., (Mountain View, CA, USA). Pomolic acid
(MW 472.71) obtained from BioBioPha Co., Ltd., (Kunming, China) was dissolved in dimethyl sulfoxide (DMSO), stored at $-20^{\circ} \mathrm{C}$ and diluted in culture medium for use. 4',6-Diamidino2-phenylindole dihydrochloride (DAPI) was from Santa Cruz Biotechnology (Santa Cruz, CA, USA).

Cell cytotoxicity assay. The MTT assay was used to measure the effect of pomolic acid (PA) on cell viability of glioblastoma cell lines. Cells were plated at a density of $1 \times 10^{4} /$ well in 96-well plate overnight and then treated with medium or different concentrations of PA $(7.5,10.0,12.5,15.0,17.5$ or $20.0 \mu \mathrm{g} / \mathrm{ml}$ equivalent to $15.86,21.15,26.44,31.73,37.02$ or $42.30 \mu \mathrm{M}$, respectively). DMSO at the higher concentration carried by PA, had no effect on cell viability. Four hours before the end of the treatment, cells were incubated with MTT $(2.5 \mathrm{mg} / \mathrm{ml})$ and kept in the dark at $37^{\circ} \mathrm{C}$ until the end of the treatment. The formazan produced by the reduction of MTT by viable cells was dissolved in DMSO, and the optical density was measured with an ELISA reader (BenchMark; Bio-Rad Laboratories, Hercules, CA, USA) at $570 \mathrm{~nm}$ (reference filter $630 \mathrm{~nm}$ ). Experiments were repeated at least three times. The results were expressed as percentage of the control, considered to be $100 \%$.

DNA fragmentation assays. DNA fragmentation was evaluated by cell cycle analysis using flow cytometry. Twenty-four hours after plating, the cells $\left(5 \times 10^{4}\right.$ cells/well $)$ were treated with medium (control) or $15 \mu \mathrm{g} / \mathrm{ml}(31.73 \mu \mathrm{M})$ PA and incubated for different times $(1,2,4,6,8$ or $24 \mathrm{~h})$. Next, cells were harvested, resuspended in HFS, a hypotonic fluorescent solution $(50 \mathrm{mg} / \mathrm{ml} \mathrm{PI}$ and $0.1 \%$ Triton X-100 in $0.1 \% \mathrm{Na}$ citrate buffer) for $1 \mathrm{~h}$ in the dark at $4^{\circ} \mathrm{C}$. The cell cycle was analyzed by flow cytometry (5,000 events, FL-2 channel) (FACSCalibur; Becton-Dickinson, San Jose, CA, USA) to determine the sub-G0/G1 DNA content. Sub-diploid populations were considered to be apoptotic. Data acquisition and analysis were controlled by CellQuest software, version 3.1f. The results are presented as representative histograms and as the mean \pm SD of the percentage of the fragmented DNA.

Measurement of mitochondrial transmembrane potential. Variations of mitochondrial membrane potential (MMP) were assessed using the fluorochrome $\mathrm{DiOC}_{6}(3)(40 \mathrm{nM})$, a compound that accumulates in viable mitochondria due to its electro-chemical gradient and leaks in response to loss of transmembrane potential. Cells were plated and treated or not with $15 \mu \mathrm{g} / \mathrm{ml}(31.73 \mu \mathrm{M})$ PA for the same periods of time described for detection of apoptosis. Then, cells were harvested, resuspended in $200 \mu 1 \mathrm{DiOC}_{6}(3)$ for $30 \mathrm{~min}$ and analyzed by flow cytometry (10,000 events, FL-1 channel). The results represent the average \pm SD of three experiments.

Caspase activation assay. Activation of caspase-3 and -9 were assayed using CaspGLOW commercial kits according to the instructions of the manufacturer (BioVision). The CaspGLOW is a sensitive method used to detect activated caspases in apoptotic cells. In brief, cells (5x10 /well) were incubated with medium (control) or with $15 \mu \mathrm{g} / \mathrm{ml}$ (31.73 $\mu \mathrm{M})$ PA for 8 or $24 \mathrm{~h}$ before being harvested, centrifuged and suspended in the caspase assay solution. This 
solution contained the caspase-3 inhibitor, DEVD-FMK, or caspase-9 inhibitor LEHD-FMK conjugated to FITC as a marker. These FITC conjugated molecules are cell permeable, non-toxic, and irreversibly bind to activated caspase-3 or caspase-9 in apoptotic cells allowing for direct detection of activated caspases in apoptotic cells by flow cytometry. After $1 \mathrm{~h}$ of incubation $\left(37^{\circ} \mathrm{C}, 5 \% \mathrm{CO}_{2}\right)$, cells were washed twice with washing buffer, and the percentage of caspaseactivated cells was analyzed by flow cytometry (FL-1). The results are presented as representative histograms and as the mean of fluorescence intensity $(\mathrm{MFI}) \pm \mathrm{SD}$.

Quantification of reactive oxygen species (ROS). ROS was determined by flow cytometry in cells treated with $\mathrm{H}_{2}$-DCFDA. GBM-1 cells seeded in 24 -well plates $\left(5 \times 10^{4}\right.$ cells/well) were incubated with medium or $15 \mu \mathrm{g} / \mathrm{ml}(31.73 \mu \mathrm{M})$ PA for 1,2 , 4, 6, 8 and $24 \mathrm{~h}$. After the desired time, cells were harvested, washed with phosphate-buffered saline (PBS), $\mathrm{pH} 7.4$, and re-suspended in $0.16 \mathrm{ml}$ PBS containing $20 \mu \mathrm{M} \mathrm{H}_{2}$-DCFDA. After $15 \mathrm{~min}$ of incubation at $37^{\circ} \mathrm{C}$, the production of ROS was evaluated by flow cytometry (FL-1 channel). Estimates of ROS following drug treatment were determined by measuring the change in mean fluorescence intensity using only live cells, which was calculated by CellQuest software. For each sample, 10,000 events were collected. To assess the role of ROS in PA cytotoxicity cells were treated for $24 \mathrm{~h}$ with media, pre-treated or not for $1 \mathrm{~h}$ with the ROS inhibitor $\mathrm{N}$-acetyl-L-cysteine (NAC, $10 \mathrm{mM})$ and then incubated with $15 \mu \mathrm{g} / \mathrm{ml}(31.73 \mu \mathrm{M})$ PA. ROS production and DNA fragmentation were evaluated after 6 and $8 \mathrm{~h}$, respectively.

Activity and expression of MDR transporter proteins. The functional activity of $\mathrm{ABC}$ proteins was determined based on the intracellular accumulation of specific substrates. For each experiment, GBM-1 cells (1x105/well) were seeded into 24-well plates and pre-incubated for $24 \mathrm{~h}$ at $37^{\circ} \mathrm{C} / 5 \%$ $\mathrm{CO}_{2}$ to allow stabilization of the culture. Platted cells were then incubated for $30 \mathrm{~min}$ with substrates specific for Pgp (200 ng/ml rhodamine 123), MRP1 (5 $\mu \mathrm{M}$ CFDA) or BCRP (3 $\mu \mathrm{M}$ mitoxantrone) in presence of medium or the conventional inhibitor of these proteins, verapamil $(50 \mu \mathrm{M})$, MK571 $(50 \mu \mathrm{M})$ and fumitremogin C $(10 \mu \mathrm{M})$, respectively. Next, cells were washed in PBS, harvested and intracellular fluorescence was evaluated in a FACSCalibur, BecktonDickinson cytometer (10,000 events; channels FL-1 or FL-3). The mean fluorescence intensity (MFI) associated with intracellular fluorescence which reflects the transporter activity of the proteins, was used to quantify their activity. The results are presented as the mean \pm SD of arbitrary units of mean fluorescence intensity.

To assess the effect of PA on MRP1 activity, platted cells were incubated for 30 min with medium (autofluorescence) or with $5 \mu \mathrm{M}$ CFDA in the presence of medium, MRP1 inhibitor (50 $\mu \mathrm{M}$ MK-571) or the desired concentrations of PA $(5,7.5$, 10. 12.5 or $15 \mu \mathrm{g} / \mathrm{ml}$ correspondent to $10.57,15.86,21.15$, 26.44 or $31.73 \mu \mathrm{M})$. After harvesting, cells were analyzed as described above. CFDA (5-carboxyfluorescein diacetate), a non-fluorescent molecule that is converted into fluorescent carboxy-fluorescein (CF) by intracellular esterases, was used. Several studies have shown that cells exhibiting high levels of the MRP1 protein actively exclude carboxy-fluorescein $(\mathrm{CF})$; CF can therefore be used as an indicator of MRP1 pump activity.

Expression of MRP1 protein was analyzed by flow cytometry. Cells were harvested, permeabilized with FACS lysing solution for $30 \mathrm{~min}$ and incubated for $10 \mathrm{~min}$ with a blocking solution (PBS with 5\% BFS). The cells were then centrifuged (1,400 rpm/5 min) and resuspended in PBS solution with an anti-MRP1 antibody (1:20 dilution) for $60 \mathrm{~min}$ at room temperature. After two washes with PBS, the cells were incubated with a FITC-labeled goat anti-rat IgG antibody $(1: 1,000)$ from Sigma-Aldrich for $30 \mathrm{~min}$. After washing with PBS, the cells were resuspended in PBS, and their fluorescence was evaluated by flow cytometry (FACSCalibur; BecktonDickinson cytometer, FL-1). The results are presented as representative histograms or mean $\pm \mathrm{SD}$ of arbitrary units of mean fluorescence intensity.

Wound healing assay. GBM-1 cells were seeded in a 24-well tissue culture plate and grown to $90 \%$ confluence. After removing the medium, a scratch was made in the middle of the well with a P200 pipette tip. Subsequently, the debris was washed with PBS and new media was added to the wells containing 5.0 or $7.5 \mu \mathrm{g} / \mathrm{ml}$ equivalent to 10.57 or $15.86 \mu \mathrm{M}$ PA. Wound closure was monitored and photographed at 0 and $24 \mathrm{~h}$ under the inverted microscope. In order to quantify the migrated cells, pictures of the initial wounded monolayers were compared with the corresponding pictures of cells at the end of the incubation. Artificial lines fitting the cutting edges were drawn on pictures of the original wounds and overlaid on the pictures of cultures after incubation. Cells that had migrated across the white area were counted in random fields from each triplicate treatment. Results were expressed as mean \pm SD from four individual experiments.

Statistical analysis. All data reported here are expressed as the mean \pm SD from three independent experiments. A significant difference from the respective control for each experimental test condition was assessed by one-way analysis of variance (ANOVA) using GraphPad Prism 4.0 software. Values of $\mathrm{P}<0.05$ were considered statistically significant.

\section{Results}

Pomolic acid induces apoptosis of GBM cells. We used MTT assay to evaluate the effects of pomolic acid (PA; Fig. 1A) on the viability of the GBM cell lines U87, A172 and GBM-1. Cells were treated with different concentrations of the triterpene for 24 or $48 \mathrm{~h}$. PA inhibits cell viability of all GBM cell lines dose- and time-dependently (Fig. 1B-D). After 24-h treatment, the $\mathrm{IC}_{50}$ for U87, A172 and GBM-1 was 11.09 \pm 1.075 , $8.82 \pm 0.205$ and $9.72 \pm 0.8294 \mu \mathrm{g} / \mathrm{ml}$, respectively. At this incubation time, $15 \mu \mathrm{g} / \mathrm{ml}$ PA decreases the viability of the cells in $70-90 \%$, indicating the high antineoplastic potential of this compound. As the activity of PA on these cells was quite similar, $\mathrm{IC}_{50}$ varying from 8.8 to $11.0 \mu \mathrm{g} / \mathrm{ml}$ after $24-\mathrm{h}$ treatment, the next experiments were performed on the GBM-1 cell line. This cell line was recently established from a GBM biopsy (25) and can better reproduce glioblastoma characteristics. 


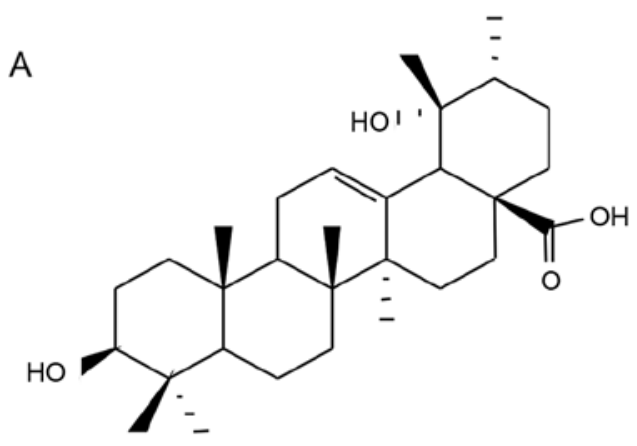

C

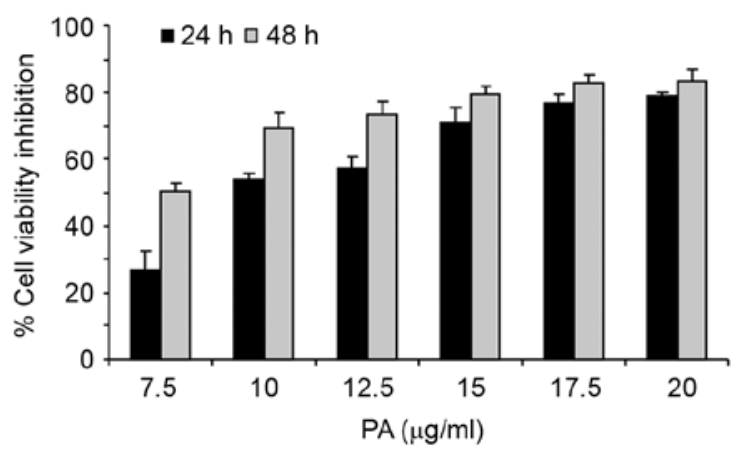

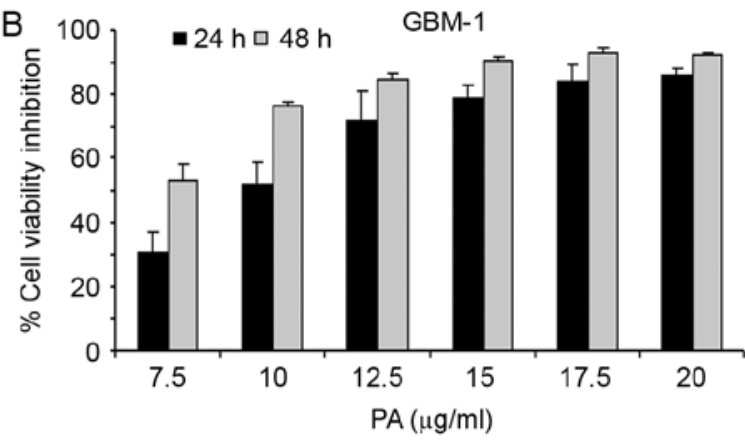

D

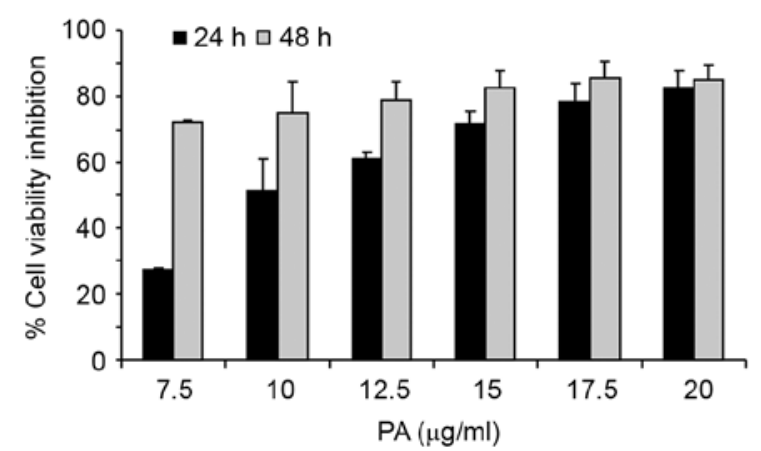

Figure 1. Pomolic acid inhibits the viability of GBM cells. (A) Chemical structure of pomolic acid (PA). (B-D) Cell viability. Cells were incubated for 24 or $48 \mathrm{~h}$ with the indicated concentration of PA then viability was determined by MTT as described in Materials and methods. Results express the mean \pm SE of three independent experiments performed in triplicate.

Next, we investigated if the cytotoxic activity of PA would be mediated by induction of apoptosis. In order to test that, GBM-1 cells were treated with $15.0 \mu \mathrm{g} / \mathrm{ml}$ PA for different time intervals $(1,2,4,6,8$ or $24 \mathrm{~h})$ and the percentage of hypodiploid nuclei in the subG1 peak of the cell cycle, indicative of apoptosis, was determined. PA induced a time-dependent increase in DNA fragmentation. After 8-h treatment, this effect is $~ 50 \%$ (Fig. 2A). Caspase-3 activation is a characteristic of the apoptosis process. To confirm that cell death is being achieved by induction of apoptosis, activation of caspase-3 was assessed. Cells were treated with PA for 8 and $24 \mathrm{~h}$ and analyzed by the CaspGLOW assay. Results in Fig. 2D show a time-dependent activation of caspase- 3 .

Since several drugs induce apoptosis through activation of the intrinsic pathway, the involvement of this pathway in PA-induced cell death was analyzed. GBM-1 cells treated in the same conditions used to measure DNA fragmentation were incubated with the fluorescent dye $\mathrm{DiOC}_{6}(3)$ and alterations of the transmembrane potential (PTP) were evaluated by cytometry. Pomolic acid induces a time-dependent decrease in mitochondria membrane potential (Fig. 2B) suggesting that the apoptotic process is mediated by activation of the intrinsic pathway. To reinforce these observations, activation of caspase- 9 was assessed. For this, cells were treated with PA for 8 and $24 \mathrm{~h}$ and analyzed by the CaspGLOW assay. Results in Fig. 2C show a time-dependent activation of caspase-9, confirming that PA induces apoptosis of GBM cells by the activation of the intrinsic pathway.

We then investigated if the oxidative stress, resulting from alterations of the mitochondria membrane permeability, was involved in PA-induced apoptotic death. For this,
DNA fragmentation and ROS production were measured in cells incubated with PA for different times. Observation that DNA fragmentation starts when production of ROS reach a peak $(6 \mathrm{~h})$ suggests its involvement on PA-induced apoptosis (Fig. 3A). To further analyze this possibility, cells were preincubated for $1 \mathrm{~h}$ with the anti-oxidant NAC then treated with PA and the production of ROS and DNA fragmentation was evaluated. Pre-treatment with NAC inhibits both, the production of ROS (Fig. 3B) and the fragmentation of DNA (Fig. 3C); reinforcing the role of ROS in PA-induced apoptosis.

Pomolic acid downmodulates activity of MRP1. ABC transporters are involved in the acquisition of the multidrugresistance (MDR) phenotype in cancer cells (5). The expression and activity of these transporters contribute to drug resistance in GBM cells (6). The expression of ABC transporter proteins in GBM cells led us to probe if they were involved in PA-induced cell death. Initially, we investigate if these proteins were functional in GBM-1 cells. Pgp and ABCG2 inhibitors were unable to block the transport of a fluorescent probe in GBM-1 cells (Fig. 4A and C) while changes were observed when cells were incubated with an MRP1 inhibitor (Fig. 4B). These data demonstrated that MRP1 is active in GBM-1 cells, while Pgp and ABCG2 are not.

Due to the important role played by MRP1 in GBM resistance $(9,11)$, we then investigated the effects of PA on the activity of this protein. For this, MRP1 activity was analyzed in the presence or absence of different concentrations of PA $(5.0 .7 .5,10.0,12.5$ and $15.0 \mu \mathrm{g} / \mathrm{ml})$. The results show that PA down-modulates MRP1 activity dose-dependently. Additionally, we observed that PA $(15 \mu \mathrm{g} / \mathrm{ml})$ inhibits MRP1 
A
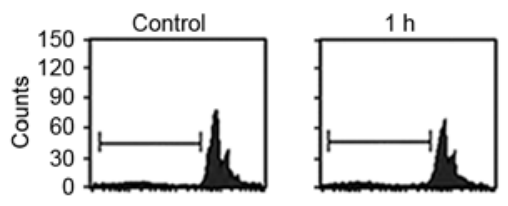

$8 \mathrm{~h}$
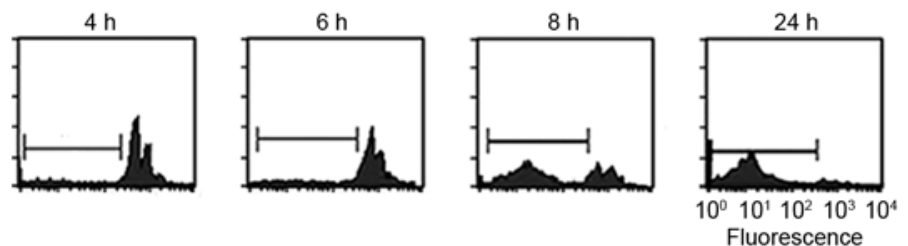

B
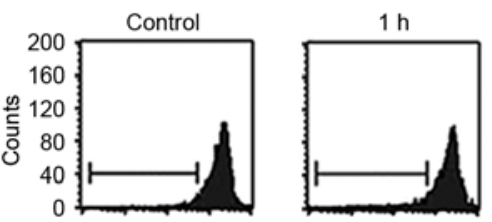

$8 \mathrm{~h}$

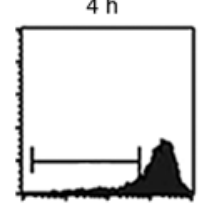

$6 \mathrm{~h}$
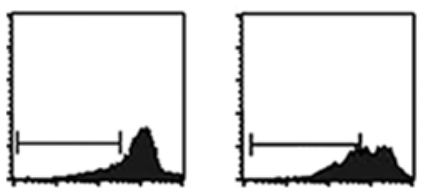

C

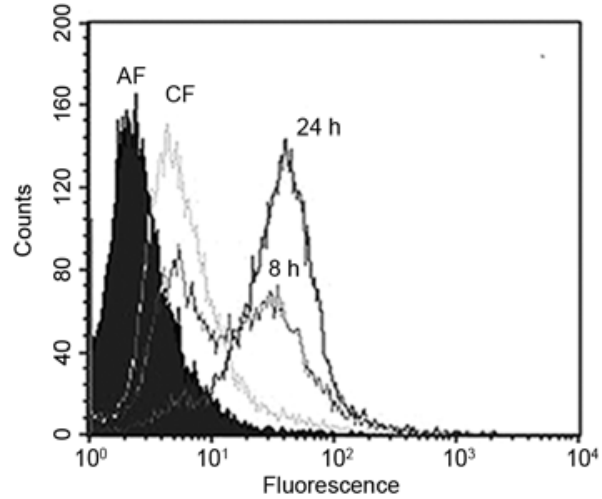

D
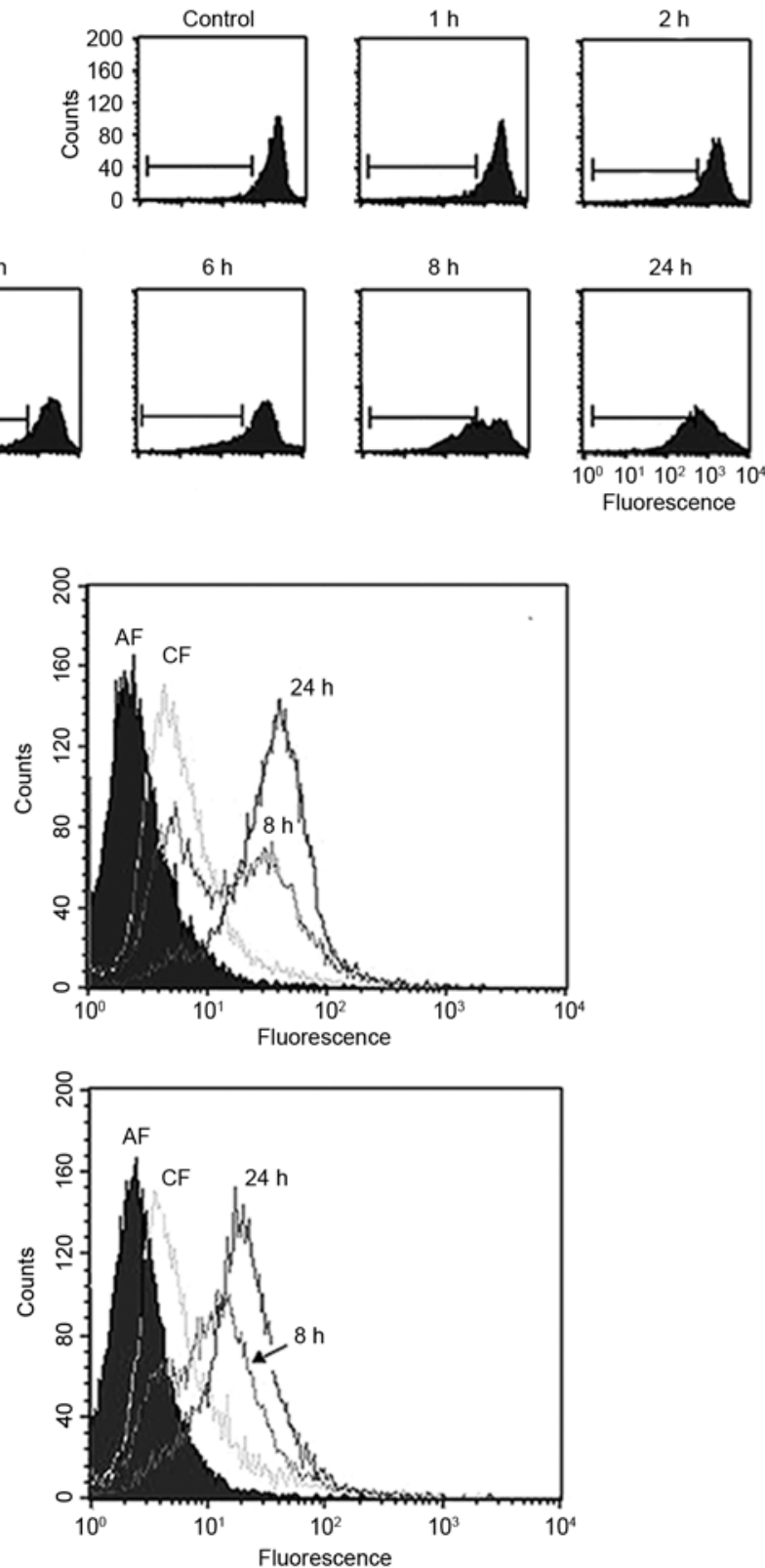
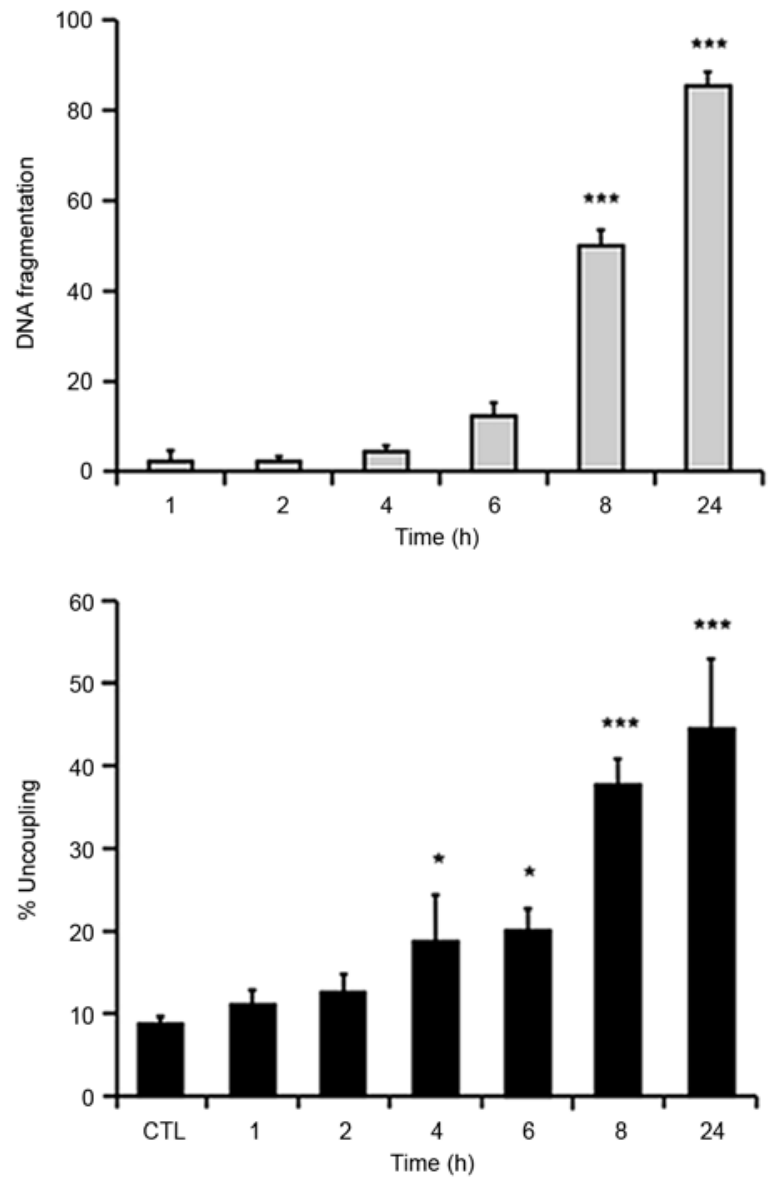
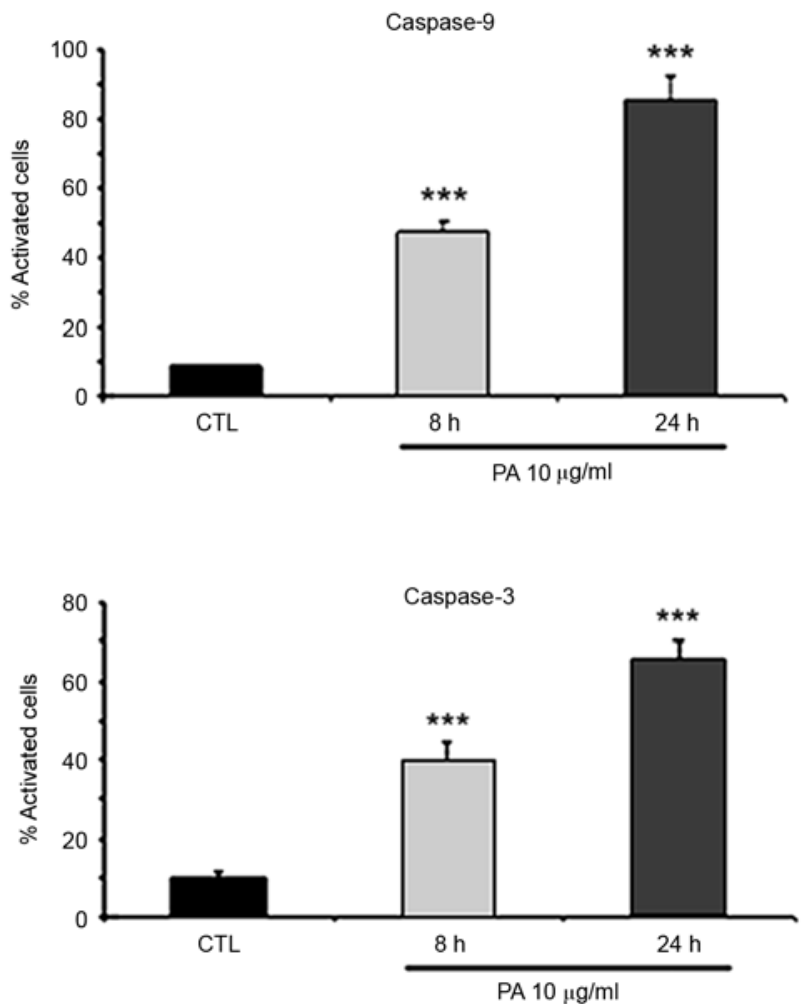

Figure 2. PA induces apoptosis of GBM-1 cells. Cells were incubated with $15 \mu \mathrm{g} / \mathrm{ml}$ PA for the indicated periods and analyzed as described in Materials and methods. (A) For determination of DNA fragmentation treated cells were ressuspended in HFS buffer and the percentage of apoptotic cells were quantified by cytometry. Left panel, representative histograms and right panel, percentage of cells with fragmented DNA. (B) For determination of the mitochondrial transmembrane potential (MTP) treated cells were incubated with $\mathrm{DiOC}_{6}(3)$ and analyzed by flow cytometry. Left panel, representative histograms and right panel, percentage of loss of membrane potential. (C and D) Determination of caspase- 9 and -3 activation was performed by flow cytometry using the CaspGLOW kit in cells treated with PA for 8 or $24 \mathrm{~h}$. Left panels, representative histograms and right panels, percentage of cells with activated caspase. Results of all experiments represent mean $\pm \mathrm{SE}$ of three experiments. ${ }^{*} \mathrm{P}<0.005$ and ${ }^{* * *} \mathrm{P}<0.0001$. 


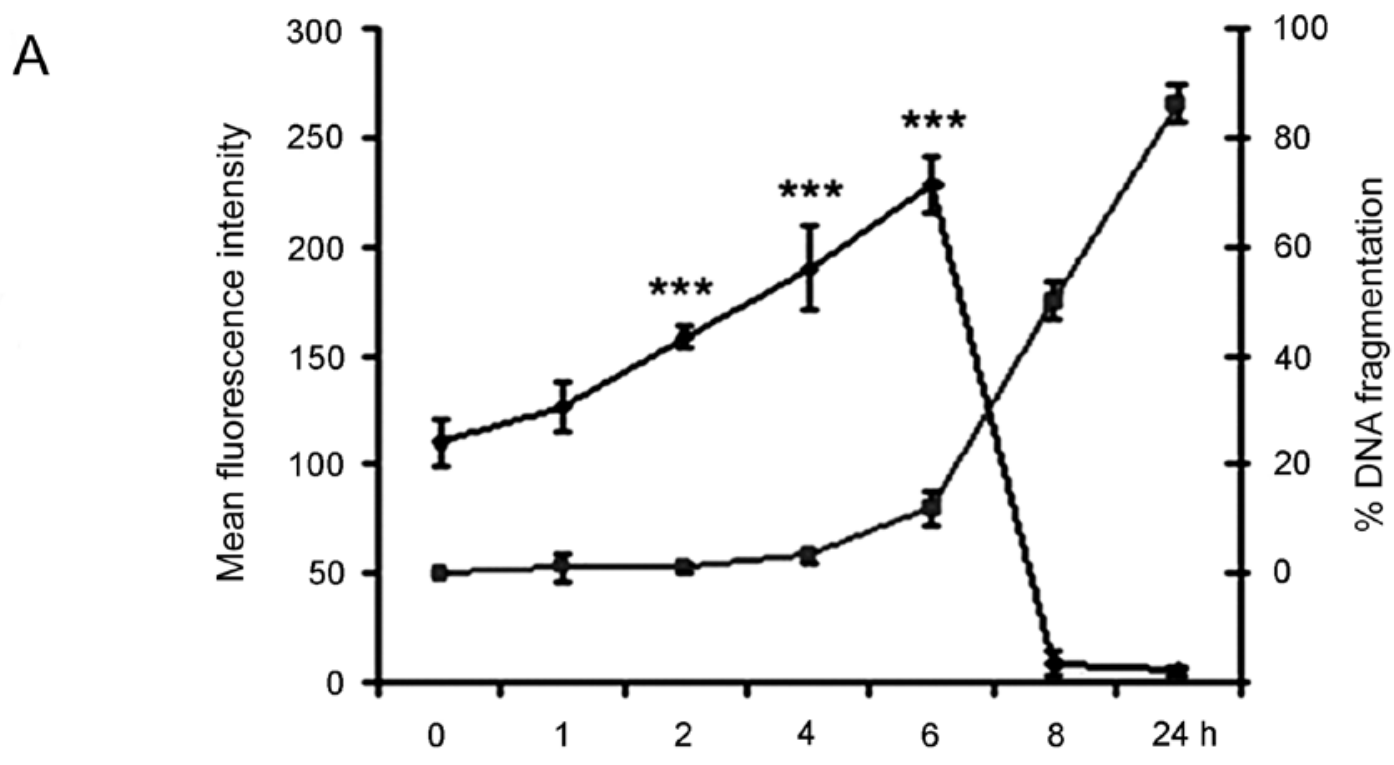

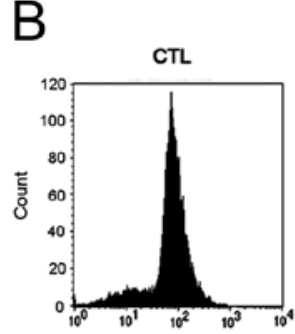
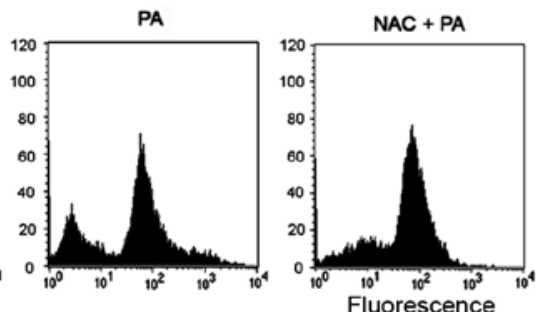

C
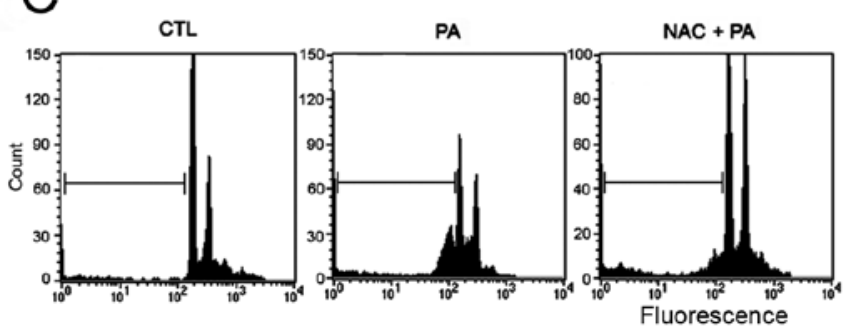

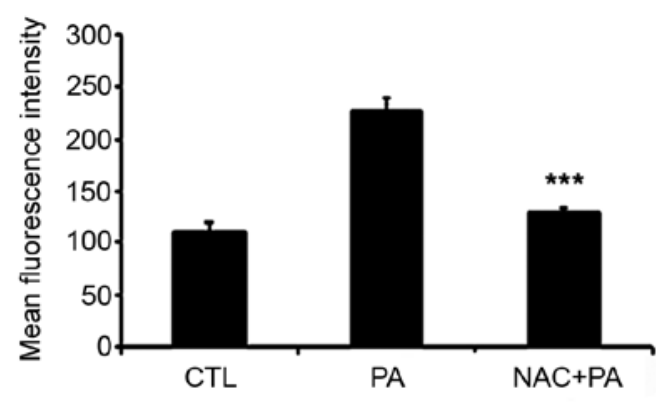

Figure 3. PA-induced cell death is mediated by ROS. (A) ROS production and DNA fragmentation. For measurement of ROS and DNA fragmentation GBM-1 cells treated with $15 \mu \mathrm{g} / \mathrm{ml}$ PA for the indicated time were incubated with $\mathrm{H}_{2}$-DCFDA or HFS buffer and the intracellular fluorescence (ROS) and percentage of apoptotic cells were evaluated by flow cytometry as described in Materials and methods. ROS production was expressed in arbitrary units (a.u.) of mean fluorescence intensity (MIF) and DNA fragmentation in percentage of apoptotic cells (B and C). For evaluation of the effects of NAC on PA-induced ROS and DNA fragmentation cells were pre-treated for $1 \mathrm{~h}$ with $10 \mathrm{mM}$ NAC and then incubated with $15 \mu \mathrm{g} / \mathrm{ml} \mathrm{PA}$ for 6 and $8 \mathrm{~h}$, respectively. Left panel, representative histograms and right panel, ROS production and DNA fragmentation. ${ }^{* * *}$ MIF values significantly different $(\mathrm{P}<0.001)$ from control $(0$ h) or different from AP+NAC treatment compared with PA alone.

activity in a similar way as the commercial inhibitor MK571 (Fig. 5A). Assessment of effects of PA treatment in MRP1 expression revealed that down-modulation of MRP1 activity is not due to inhibition of protein expression (Fig. 5B).

Pomolic acid inhibits migration of GBM cells. Glioblastomas are highly invasive tumors. Tumor cell migration and diffuse infiltration into brain parenchyma are known mechanisms of tumor recurrence (13). To further explore the potential of PA as a tool to treat GBM, we used wound healing assay to investigate the effect of this triterpene on the migration of GBM-1 cells. The treatment of glioblastoma cells with low concentrations of PA $(5.0$ or $7.5 \mu \mathrm{g} / \mathrm{ml})$ for $24 \mathrm{~h}$ significantly inhibited migration (Fig. 6).

\section{Discussion}

Malignant central nervous system neoplasms, particularly GBMs, are included among the most lethal and intractable human tumors defying all current therapeutic modalities and presenting a poor patient prognosis. Almost all GBM patients undergo tumor recurrence and only a small percentage of the patients survived 2 years after the treatment. The standard GBM treatment, which consists of surgical resection, radiation and/or chemotherapy, is rarely curative. The diffuse growth pattern of GBM prevents complete resection of the tumor, requiring additional therapy. Moreover, tumor cell resistance to chemo-radiation contributes to the poor prognosis of the disease $(1,2)$. Thus, despite the massive research efforts, the 

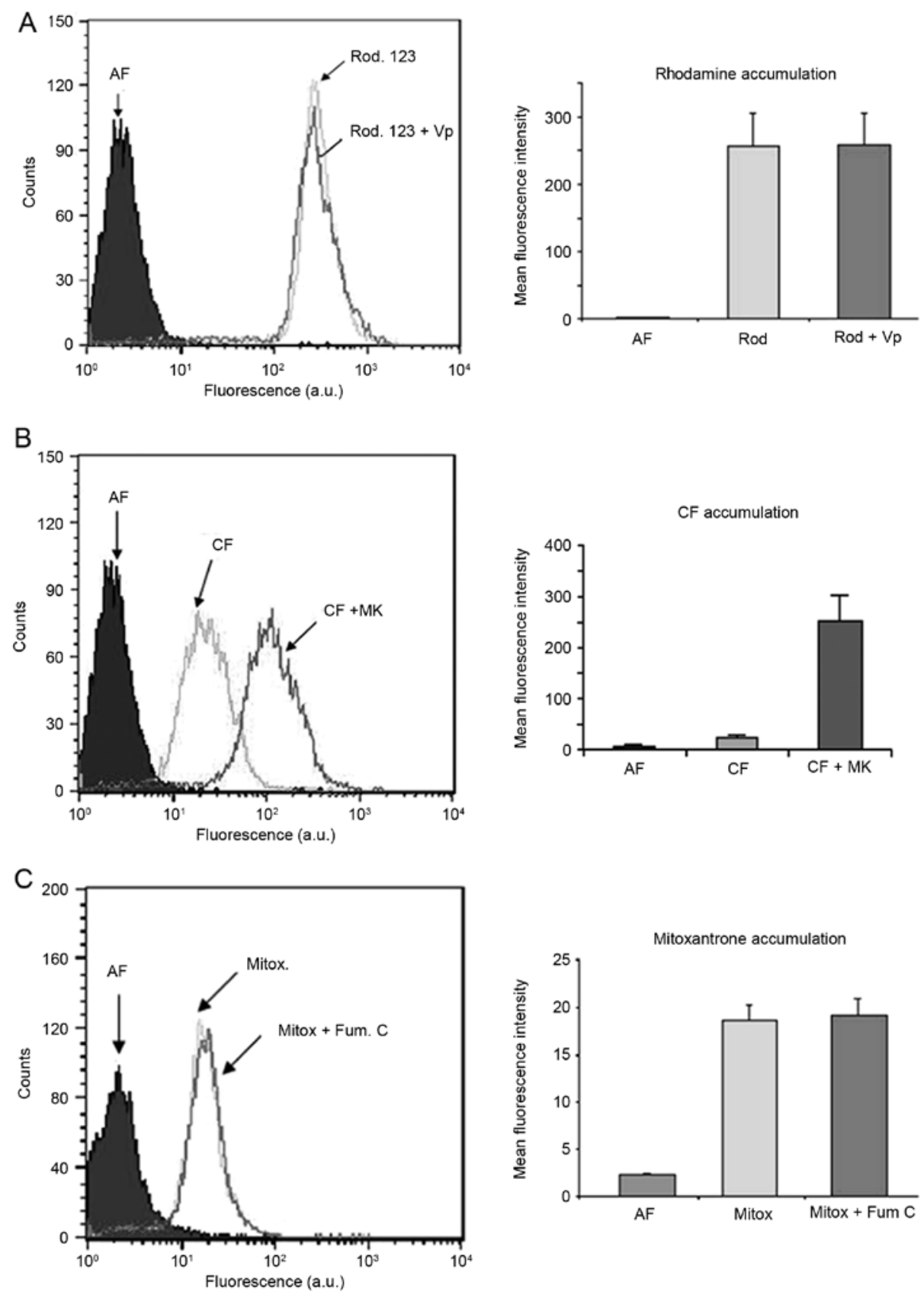

Figure 4. Functional activity of ABC transporters. (A-C) Platted cells were incubated with substrates specific for Pgp (200 ng/ml rhodamine 123), MRP1 $(5 \mu \mathrm{M}$ CFDA) or BCRP ( $3 \mu \mathrm{M}$ mitoxantrone) in presence of medium or the conventional inhibitor of these proteins verapamil $(50 \mu \mathrm{M})$, MK571 (50 $\mu \mathrm{M})$ and fumitremorgin $\mathrm{C}(10 \mu \mathrm{M})$, respectively. Intracellular fluorescence was evaluated by flow cytometry. Left panels, representative histograms and right panels, arbitrary units (a.u.) of mean fluorescence intensity (MIF). Results present mean \pm SD of three experiments.

outcome of these tumors remain dismal stressing the need for new drugs or strategies able to improve the patient survival.

In the last few years, natural products have been recognized as an important source of novel antineoplastic drugs. Accumulating evidence on the antitumor activity of triterpenes supports these materials as one of these drug sources $(14,26,28)$. However, although the antitumoral activities of pomolic acid (Fig. 1A) against different cancer cell lines have been described $(19,21-23)$, there is no previous information on its effect on GBM cell lines. Data presented in the present study (Fig. 1B-D) show that PA has a potent antitumoral activity against GBM cell lines (U87, A172 and GBM-1) decreasing their viability up to $70-90 \%$ after 24 -h treatment.
The apoptotic cell death program is compromised in GBM, leading to a survival advantage of the tumor cells. Alterations of pathways that control apoptosis make GBM virtually resistant to apoptotic stimuli. Results showing that PA induces apoptosis by activation of the intrinsic/mitochondrial pathway are in agreement with previous literature data showing that PA induced uncoupling of mitochondria membrane potential (20) and apoptosis of different tumor cell lines $(19,23,29)$. Accumulating data from several reports described the susceptibility of tumor cells to increased oxidative stress $(30,31)$ and showed ROS as an important mediator of the cytotoxic activity of several drugs (4). The present study demonstrates that treatment with PA doubles the level 

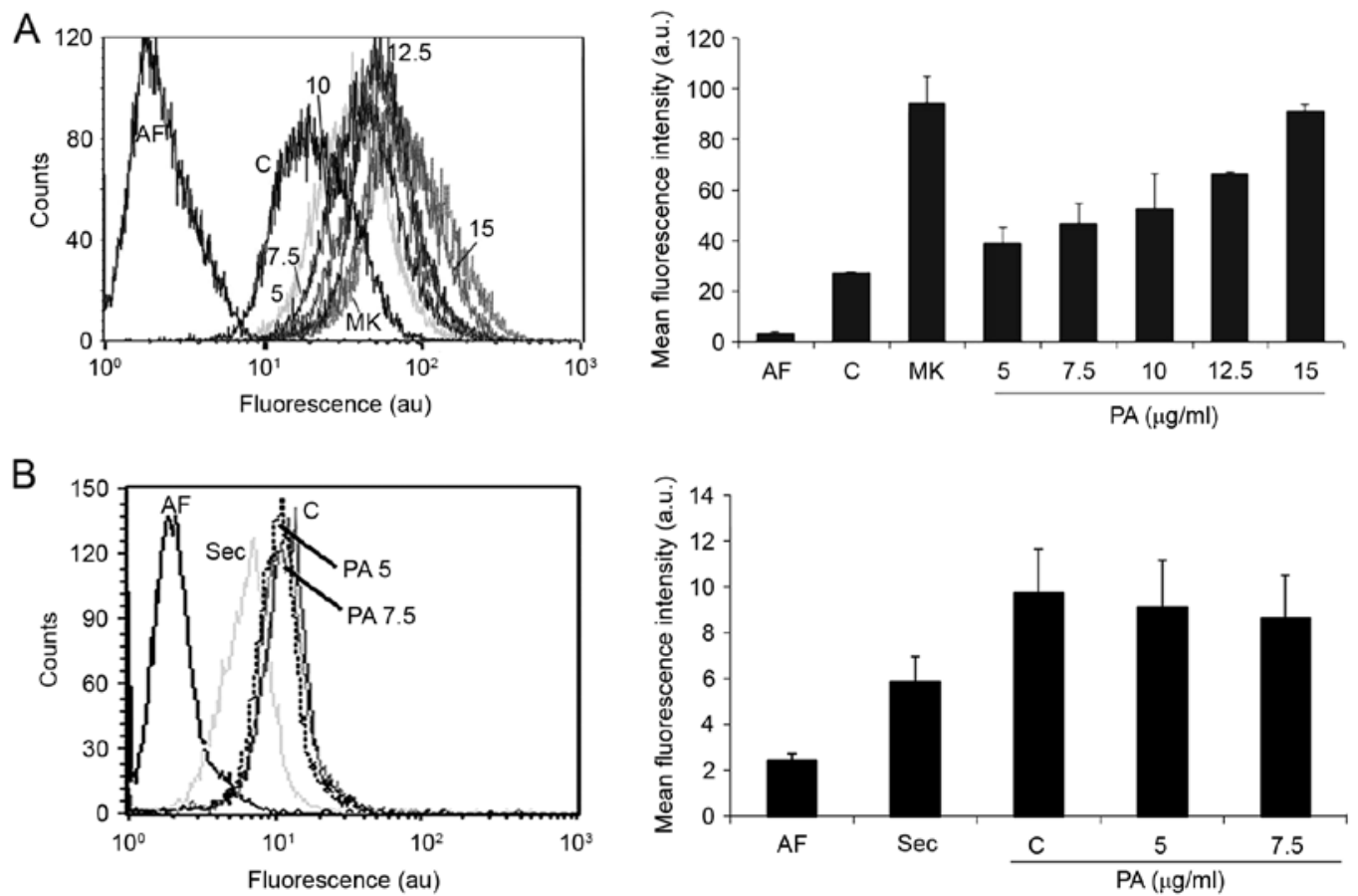

Figure 5. Effects of PA on MRP1 activity and expression. (A) MRP1 activity. Cells were incubated with CFDA C or CFDA plus PA (5, 7.5, 10. 12.5 or 15 $\mu \mathrm{g} / \mathrm{ml})$ or MK571 $(50 \mu \mathrm{M})$ and intracellular fluorescence was determined by flow cytometry. (B) MRP1 expression. Cells were treated with medium C, 5.0 or $7.5 \mu \mathrm{g} /$ $\mathrm{ml}$ PA for $24 \mathrm{~h}$, treated with monoclonal antibodies specific for MRP1, FITC-labelled secondary antibodies, then fluorescence was evaluated by cytometry as described in Materials and methods. Left panel, representative histogram and right panel, arbitrary units (a.u.) of mean fluorescence intensity (MIF). Results present mean $\pm \mathrm{SD}$ of three experiments.
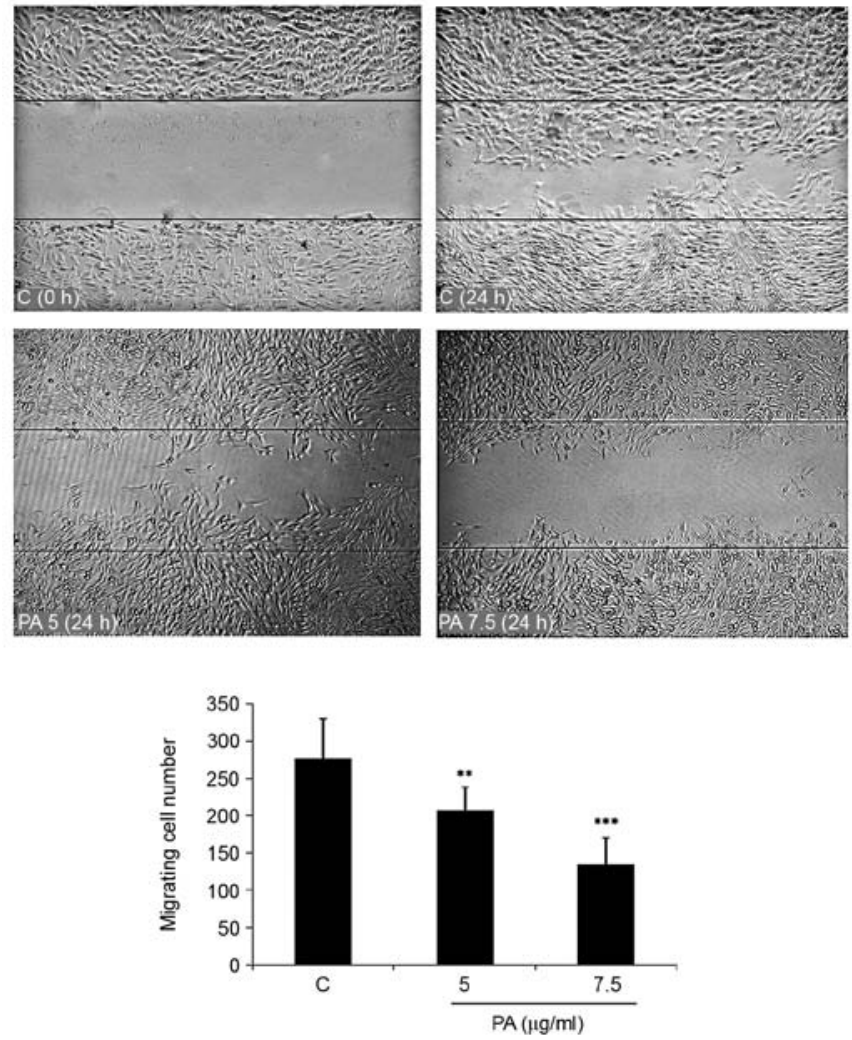

Figure 6. PA inhibits GBM-1 cell migration. Confluent cells were scraped with P200 pipette tip, treated with medium, 5.0 or $7.5 \mu \mathrm{g} / \mathrm{ml}$ PA for $24 \mathrm{~h}$ and their migration was evaluated by microscopy as described in Materials and methods. Upper panel, representative micrographs of cell migration (wound scratch). Lower panel, quantification of cells on scratch. Data are presented as mean \pm SD of three independent experiments. ${ }^{* *} \mathrm{P}<0.01$ and ${ }^{* * * *} \mathrm{P}<0.001$ represent significant difference between PA-treated groups and the control. of ROS in the GBM cells. Addition of NAC inhibits both ROS and DNA fragmentation (Fig. 3B and C) demonstrating the dependence of PA-induced cell death on ROS production. Moreover, as GBM resistance to temozolomide (TMZ) has been associated with increased mitochondria coupling and reduction of ROS production (32), it is possible that a prooxidant therapy may also work as an anti-MDR strategy to evercome drug-resistance in GBM.

Extrusion of drugs by plasma membrane transporters of the ABC family of proteins is a well recognized mechanism of chemoresistance (5). In gliomas, expression of these proteins has been correlated with the tumor grade, being higher in GBMs (33). Increased expression of ATP-dependent drug efflux pumps was observed after chemotherapy (34) in glioma cancer stem cells (CSC) from GBM patients (35) and have been associated with TMZ resistance $(36,37)$. Thus, drug resistance mediated by these proteins, decreases the efficacy of treatment, favoring the maintenance of a residual disease from which the tumor grows. Amongst the ABC proteins, members of the MRP family seem to be particularly important for GBM drug resistance as expression of these proteins increase in high-grade gliomas $(9,33)$, in recurrent GBM (12), and correlate with poor patient prognosis $(8,9)$. In the present study, we show that PA induces apoptosis of GBM cell lines expressing an active MRP1/ABCC1 (Fig. 4B) and down-modulates the activity of this protein without altering its expression (Fig. 5A and B). These results support previous literature data showing that inhibition of MRP1 activity chemosensitize GBM cells leading to increased drug cytotoxicity $(13,38,39)$. Previous results from our group demonstrated that PA is effective against cancer MDR cells whose resis- 
tance mechanism is mediated by overexpression of the MDR protein Pgp/ABCB1 (19) and cells expressing, simultaneously, different MDR mechanisms (29). Thus, the ability of PA to overcome resistance mediated by different $\mathrm{ABC}$ transporters may be useful for GBM control and also to other tumor types expressing this family of transporters.

However, in addition to drug resistance mechanisms, the high invasive nature of glioblastoma cells has also been indicated as an important factor to the failure of current therapeutic approaches (13) and as a result, to tumor recurrence. Thus, identifying new agents that target migration and invasion processes can be of great importance for the prognosis of GBM. Cell invasion is a complex process with multiple biologic features (40), in which cell migration is one of the first steps. Results in the present study showing that PA dose-dependently decreased GBM cell invasiveness indicate a possible role for this triterpene in reducing recurrence and metastasis. Indeed an inhibitory effect of PA on breast cancer cell migration was also reported (18).

Despite the advances on GBM therapy there is still an urgent need for treatments that are more effective and able to bypass the tumor mechanisms of drug resistance. Natural products are emerging as an important source of new potential candidates for the treatment or as adjuvant therapy for glioblastoma (41-44). In GBM, natural triterpenes were shown to induce cell arrest and/or apoptosis both in vitro $(45,46)$ and in vivo (47), to inhibit migration and invasion (48) and to attenuate TMZ resistance (49). Results presented in this study show that the pentacyclic triterpene pomolic acid (PA) is cytotoxic to GBM cell lines and that this effect is associated with induction of apoptosis, uncoupling of mitochondria potential, increase in ROS production and modulation of MDR pump, MRP1/ABCC1 activity. The mechanism of PA drug action appears to be a combination of increased redox mediated cytotoxicity and modulation of MDR mechanisms. The ability of PA to cross the blood-brain-barrier was not investigated; however, since PA is able to bypass resistance mechanisms mediated by Pgp (19) and down-modulates MRP1 activity, this possibility cannot be discarded yet. Together, the results present herein and in other studies $(19,24,29)$, showing that PA bypass different mechanisms of cell death resistance and inhibits tumor cell migration, demonstrate the potential of this compound to control tumor progression. They also call attention to PA as a possible new strategy to improve cancer therapy protocols for GBM.

\section{Acknowledgements}

The present study was supported by grants from Fundação de Amparo a Pesquisa do Estado do Rio de Janeiro (FAPERJ), Instituto Nacional para Pesquisa Translacional em Saúde e Ambiente na Região Amazônica/Conselho Nacional de Desenvolvimento Científico e Tecnológico/MCT, Brazil (INCT-INPeTAm/CNPq/MCT) and Fundação do Câncer. The authors wish to thank the Conselho Nacional de Desenvolvimento Científico e Tecnológico (CNPq) and Conselho de Aperfeiçoamento do Pessoal de Nível Superior (CAPES) for the graduate fellowships awarded to Lívia Paes Tavares Pacheco Guimarães, Rafaela Muniz de Queiroz and Carollina de Araújo Martins.

\section{References}

1. Clarke J, Butowski N and Chang S: Recent advances in therapy for glioblastoma. Arch Neurol 67: 279-283, 2010.

2. Stupp R, Hegi ME, Mason WP, van den Bent MJ, Taphoorn MJ, Janzer RC, Ludwin SK, Allgeier A, Fisher B, Belanger K, et al; European Organisation for Research and Treatment of Cancer Brain Tumour and Radiation Oncology Groups; National Cancer Institute of Canada Clinical Trials Group: Effects of radiotherapy with concomitant and adjuvant temozolomide versus radiotherapy alone on survival in glioblastoma in a randomised phase III study: 5-year analysis of the EORTC-NCIC trial. Lancet Oncol 10: 459-466, 2009.

3. Igney FH and Krammer PH: Death and anti-death: Tumour resistance to apoptosis. Nat Rev Cancer 2: 277-288, 2002.

4. Trachootham D, Alexandre J and Huang P: Targeting cancer cells by ROS-mediated mechanisms: A radical therapeutic approach? Nat Rev Drug Discov 8: 579-591, 2009.

5. Sharom FJ: ABC multidrug transporters: Structure, function and role in chemoresistance. Pharmacogenomics 9: 105-127, 2008.

6. Declèves X, Amiel A, Delattre JY and Scherrmann JM: Role of $\mathrm{ABC}$ transporters in the chemoresistance of human gliomas. Curr Cancer Drug Targets 6: 433-445, 2006.

7. Lu C and Shervington A: Chemoresistance in gliomas. Mol Cell Biochem 312: 71-80, 2008.

8. Nakagawa T, Ido K, Sakuma T, Takeuchi H, Sato K and Kubota T: Prognostic significance of the immunohistochemical expression of $\mathrm{O}^{6}$-methylguanine-DNA methyltransferase, P-glycoprotein, and multidrug resistance protein-1 in glioblastomas. Neuropathology 29: 379-388, 2009.

9. Declèves X, Fajac A, Lehmann-Che J, Tardy M, Mercier C, Hurbain I, Laplanche JL, Bernaudin JF and Scherrmann JM: Molecular and functional MDR1-Pgp and MRPs expression in human glioblastoma multiforme cell lines. Int J Cancer 98: 173-180, 2002.

10. Tivnan A, Zakaria Z, O'Leary C, Kögel D, Pokorny JL, Sarkaria JN and Prehn JHM: Inhibition of multidrug resistance protein 1 (MRP1) improves chemotherapy drug response in primary and recurrent glioblastoma multiforme. Front Neurosci 9: 218, 2015.

11. Peigñan L, Garrido W, Segura R, Melo R, Rojas D, Cárcamo JG, San Martín R and Quezada C: Combined use of anticancer drugs and an inhibitor of multiple drug resistance-associated protein-1 increases sensitivity and decreases survival of glioblastoma multiforme cells in vitro. Neurochem Res 36: 1397-1406, 2011.

12. Giese A, Bjerkvig R, Berens ME and Westphal M: Cost of migration: Invasion of malignant gliomas and implications for treatment. J Clin Oncol 21: 1624-1636, 2003.

13. Demuth T and Berens ME: Molecular mechanisms of glioma cell migration and invasion. J Neurooncol 70: 217-228, 2004.

14. Salvador JAR, Moreira VM, Gonçalves BMF, Leal AS and Jing Y: Ursane-type pentacyclic triterpenoids as useful platforms to discover anticancer drugs. Nat Prod Rep 29: 1463-1479, 2012.

15. Banno N, Akihisa T, Tokuda H, Yasukawa K, Higashihara H, Ukiya M, Watanabe K, Kimura Y, Hasegawa J and Nishino H: Triterpene acids from the leaves of Perilla frutescens and their anti-inflammatory and antitumor-promoting effects. Biosci Biotechnol Biochem 68: 85-90, 2004.

16. Lee MS and Thuong PT: Stimulation of glucose uptake by triterpenoids from Weigela subsessilis. Phytother Res 24: 49-53, 2010.

17. Alvarado-Castillo C, Estrada O and Carvajal E: Pomolic acid, triterpenoid isolated from Licania pittieri, as competitive antagonist of ADP-induced aggregation of human platelets. Phytomedicine 19: 484-487, 2012.

18. Park JH, Cho YY, Yoon SW and Park B: Suppression of MMP-9 and FAK expression by pomolic acid via blocking of NF- $\mathrm{KB} /$ ERK/mTOR signaling pathways in growth factor-stimulated human breast cancer cells. Int J Oncol 49: 1230-1240, 2016.

19. Fernandes J, Castilho RO, da Costa MR, Wagner-Souza K, Coelho Kaplan MA and Gattass CR: Pentacyclic triterpenes from Chrysobalanaceae species: Cytotoxicity on multidrug resistant and sensitive leukemia cell lines. Cancer Lett 190: 165-169, 2003.

20. Fernandes J, Weinlich R, Castilho RO, Kaplan MA, Amarante-Mendes GP and Gattass CR: Pomolic acid triggers mitochondria-dependent apoptotic cell death in leukemia cell line. Cancer Lett 219: 49-55, 2005. 
21. Yoshida M, Fuchigami M, Nagao T, Okabe H, Matsunaga K, Takata J, Karube Y, Tsuchihashi R, Kinjo J, Mihashi K, et al: Antiproliferative constituents from Umbelliferae plants VII. Active triterpenes and rosmarinic acid from Centella asiatica. Biol Pharm Bull 28: 173-175, 2005.

22. Youn SH, Lee JS, Lee MS, Cha EY, Thuong PT, Kim JR and Chang ES: Anticancer properties of pomolic acid-induced AMP-activated protein kinase activation in MCF7 human breast cancer cells. Biol Pharm Bull 35: 105-110, 2012

23. Yoo KH, Park JH, Lee DK, Fu YY, Baek NI and Chung IS: Pomolic acid induces apoptosis in SK-OV-3 human ovarian adenocarcinoma cells through the mitochondrial-mediated intrinsic and death receptor-induced extrinsic pathways. Oncol Lett 5: 386-390, 2013.

24. Fernandes J, Weinlich R, Castilho RO, Amarante-Mendes GP and Gattass CR: Pomolic acid may overcome multidrug resistance mediated by overexpression of anti-apoptotic $\mathrm{Bcl}-2$ proteins. Cancer Lett 245: 315-320, 2007.

25. Fernandes J, da Fonseca CO, Teixeira A and Gattass CR: Perillyl alcohol induces apoptosis in human glioblastoma multiforme cells. Oncol Rep 13: 943-947, 2005.

26. Shanmugam MK, Nguyen AH, Kumar AP, Tan BK and Sethi G: Targeted inhibition of tumor proliferation, survival, and metastasis by pentacyclic triterpenoids: Potential role in prevention and therapy of cancer. Cancer Lett 320: 158-170, 2012.

27. Patlolla JM and Rao CV: Triterpenoids for cancer prevention and treatment: Current status and future prospects. Curr Pharm Biotechnol 13: 147-155, 2012.

28. Gheorgheosu D, Duicu O, Dehelean C, Şoica C and Muntean D Betulinic acid as a potent and complex antitumor phytochemical: A minireview. Anticancer Agents Med Chem 14: 936-945, 2014.

29. Vasconcelos FC, Gattass CR, Rumjanek VM and Maia RC: Pomolic acid-induced apoptosis in cells from patients with chronic myeloid leukemia exhibiting different drug resistance profile. Invest New Drugs 25: 525-533, 2007.

30. Ravindran J, Gupta N, Agrawal M, Bala Bhaskar AS and Lakshmana Rao PV: Modulation of ROS/MAPK signaling pathways by okadaic acid leads to cell death via, mitochondrial mediated caspase-dependent mechanism. Apoptosis 16: 145-161, 2011.

31. Pelicano H, Carney D and Huang P: ROS stress in cancer cells and therapeutic implications. Drug Resist Updat 7: 97-110, 2004.

32. Oliva CR, Moellering DR, Gillespie GY and Griguer CE: Acquisition of chemoresistance in gliomas is associated with increased mitochondrial coupling and decreased ROS production. PLoS One 6:1-10, e24665, 2011.

33. de Faria GP, de Oliveira JA, de Oliveira JG, Romano SO, Neto VM and Maia RC: Differences in the expression pattern of P-glycoprotein and MRP1 in low-grade and high-grade gliomas. Cancer Invest 26: 883-889, 2008.

34. Abe T, Mori T, Wakabayashi Y, Nakagawa M, Cole SP, Koike K, Kuwano $\mathrm{M}$ and Hori S: Expression of multidrug resistance protein gene in patients with glioma after chemotherapy. J Neurooncol 40: 11-18, 1998.

35. Jin F, Zhao L, Guo YJ, Zhao WJ, Zhang H, Wang HT, Shao T, Zhang SL, Wei YJ, Feng J, et al: Influence of Etoposide on antiapoptotic and multidrug resistance-associated protein genes in CD133 positive U251 glioblastoma stem-like cells. Brain Res 1336: 103-111, 2010

36. Happold C, Roth P, Wick W, Schmidt N, Florea AM, Silginer M, Reifenberger G and Weller M: Distinct molecular mechanisms of acquired resistance to temozolomide in glioblastoma cells. J Neurochem 122: 444-455, 2012.
37. Perazzoli G, Prados J, Ortiz R, Caba O, Cabeza L, Berdasco M, Gónzalez B and Melguizo C: Temozolomide resistance in glioblastoma cell lines: Implication of MGMT, MMR, P-Glycoprotein and CD133 expression. PLoS One 10: e0140131, 2015.

38. Benyahia $B$, Huguet $S$, Declèves $X$ and Mokhtari K: Crinière1 $E$, Bernaudin JF, Scherrmann JM and Delattre JY: Multidrug resistance-associated protein MRP1 expression in human gliomas: chemosensitization to vincristine and etoposide by indomethacin in human glioma cell lines overexpressing MRP. J Neurooncol 66: 65-70, 2004.

39. Garrido W, Muñoz M, San Martín R and Quezada C: FK506 confers chemosensitivity to anticancer drugs in glioblastoma multiforme cells by decreasing the expression of the multiple resistance-associated protein-1. Biochem Biophys Res Commun 411: 62-68, 2011

40. Lefranc F, Brotchi J and Kiss R: Possible future issues in the treatment of glioblastomas: Special emphasis on cell migration and the resistance of migrating glioblastoma cells to apoptosis. J Clin Oncol 23: 2411-2422, 2005 .

41. Queiroz RM, Takiya CM, Guimarães LPTP, Rocha GG, Alviano DS, Blank AF, Alviano CS and Gattass CR: Apoptosisinducing effects of Melissa officinalis L. essential oil in glioblastoma multiforme cells. Cancer Invest 32: 226-235, 2014.

42. Santos BL, Oliveira MN, Coelho PL, Pitanga BP, da Silva AB, Adelita T, Silva VD, Costa Mde F, El-Bachá RS, Tardy M, Chneiweiss H, Junier MP, Moura-Neto V and Costa SL: Flavonoids suppress human glioblastoma cell growth by inhibiting cell metabolism, migration, and by regulating extracellular matrix proteins and metalloproteinases expression. Chem Biol Int 242: 123-138, 2015.

43. da Fonseca CO, Simão M, Lins IR, Caetano RO, Futuro D and Quirico-Santos T: Efficacy of monoterpene perillyl alcohol upon survival rate of patients with recurrent glioblastoma. J Cancer Res Clin Oncol 137: 287-293, 2011.

44. Cho HY, Wang W, Jhaveri N, Torres S, Tseng J, Leong MN Lee DJ, Goldkorn A, Xu T, Petasis NA, et al: Perillyl alcohol for the treatment of temozolomide-resistant gliomas. Mol Cancer Ther 11: 2462-2472, 2012.

45. Jeremias I, Steiner HH, Benner A, Debatin KM and HeroldMende C: Cell death induction by betulinic acid, ceramide and TRAIL in primary glioblastoma multiforme cells. Acta Neurochir (Wien) 146: 721-729, 2004.

46. Li S, Zhu JH, Cao LP, Sun Q, Liu HD, Li WD, Li JS and Hang CH: Growth inhibitory in vitro effects of glycyrrhizic acid in U251 glioblastoma cell line. Neurol Sci 35: 1115-1120, 2014

47. Kavitha CV, Jain AK, Agarwal C, Pierce A, Keating A, Huber KM, Serkova NJ, Wempe MF, Agarwal R and Deep G: Asiatic acid induces endoplasmic reticulum stress and apoptotic death in glioblastoma multiforme cells both in vitro and in vivo. Mol Carcinog 54: 1417-1429, 2015

48. Guo G, Yao W, Zhang Q and Bo Y: Oleanolic acid suppresses migration and invasion of malignant glioma cells by inactivating MAPK/ERK signaling pathway. PLoS One 8: e72079, 2013.

49. Zhu Z, Du S, Ding F, Guo S, Ying G and Yan Z: Ursolic acid attenuates temozolomide resistance in glioblastoma cells by downregulating $\mathrm{O}^{6}$-methylguanine-DNA methyltransferase (MGMT) expression. Am J Transl Res 8:3299-3308. eCollection, 2016. 